\title{
Provenance and Paleoenvironmental Studies of Cretaceous African and South American Kaolins: Similarities and Differences
}

\author{
Olaonipekun Oyebanjo ${ }^{1,2}$, Nenita Bukalo ${ }^{1, *} \mathbb{E}$ and Georges-Ivo Ekosse ${ }^{1(\mathbb{C}}$ \\ 1 Directorate of Research and Innovation, University of Venda, Thohoyandou 0950, South Africa; \\ 15018001@mvula.univen.ac.za or oladayo2004@yahoo.com (O.O.); ekosseg@gmail.com (G.-I.E.) \\ 2 Natural History Museum, Obafemi Awolowo University, Ile-Ife 220282, Nigeria \\ * Correspondence: 14014934@mvula.univen.ac.za or nenitabukalo@gmail.com; Tel.: +27-15-962-8504
}

Citation: Oyebanjo, O.; Bukalo, N.;

Ekosse, G.-I. Provenance and

Paleoenvironmental Studies of

Cretaceous African and South

American Kaolins: Similarities and

Differences. Minerals 2021, 11, 1074.

https://doi.org/10.3390/

$\min 11101074$

Academic Editor: Harald G. Dill

Received: 17 August 2021

Accepted: 27 September 2021

Published: 30 September 2021

Publisher's Note: MDPI stays neutral with regard to jurisdictional claims in published maps and institutional affiliations.

Copyright: (C) 2021 by the authors. Licensee MDPI, Basel, Switzerland. This article is an open access article distributed under the terms and conditions of the Creative Commons Attribution (CC BY) license (https:/ / creativecommons.org/licenses/by/ $4.0 /)$.

\begin{abstract}
The African and South American continents are of great interest in continental drift studies. Hence, this study assesses the possible correlations in the provenance and paleoenvironment of selected Cretaceous Nigerian and Cameroonian (in Africa), and Argentine and Brazilian (in South America) kaolins through an analysis of their mineralogical and geochemical characteristics. On the basis of their mineralogical composition, the Nigerian Lakiri and Brazilian soft Capim River kaolins are predominantly characterised as pure kaolins, whereas the kaolins from Cameroon (except for Yatchika) and Argentina are mainly considered as sandy kaolins. The present study revealed that the Brazilian soft Capim River kaolin had the highest kaolinite structural order, whilst the Argentine Santa Cruz kaolin had the least. The kaolins from Nigeria, Cameroon, and Argentina were dominated by subhedral to anhedral kaolinite crystals relative to the Brazilian kaolin, which possess more euhedral kaolinite crystals. The kaolins were formed by the intense weathering of intermediate to felsic rocks under anoxic conditions, which is consistent with the structural framework of the basins. The average paleotemperatures obtained for the kaolins (except for the one from Santa Cruz) indicates that the paleoweathering took place under tropical climates.
\end{abstract}

Keywords: correlation; kaolinite; paleoweathering; paleoredox; paleotemperature

\section{Introduction}

The continental drift hypothesis supported by German meteorologist and geophysicist Alfred Wegener in 1912 was revitalised in the 1960s with the emergence of the plate tectonic theory and the discovery of seafloor spreading [1]. The emergence demonstrated that the separation of continental masses with the subsequent formation of ocean basins cannot be simply considered as a hypothesis lacking geological mechanism to explain the drifting of the continents [2], but a fact [3]. During the Early Cretaceous (approximately $130 \mathrm{Ma}$ ), the South American plate began to drift westwards from the African plate, which allowed for the opening of the South Atlantic Ocean [4]. Complementary shapes along the margin of the continents were first recognised by Dutch scientist Ortelius in 1596 [5]. These striking similarities in their coastlines in the South Atlantic Ocean have stimulated several scientific, geological, and geochronological research to validate the fact that their similarities are more than mere coincidence [4-10].

Comparative quantitative tests have been made between the two continental masses with the advent of radiometric dating [11-14]. Hurley et al. [11] substantiated the geochronological evolution of the similarities between basement rocks in Liberia and Sierra Leone in West Africa and analogous rocks in Venezuela, Guyana, and Surinam in South America. This is attributed to a major episode of orogeny in the middle Precambrian called Eburnean in Africa and Transamazonian in South America, which was later corroborated by Tugarinov [15]. Furthermore, the induced granitisation processes associated with these orogenies, 
which led to the formation of granitic rocks of different types in both regions, were later identified as a means for pre-drift reconstruction, such as pegmatitic provinces or tin (Sn) mineralisation in both continents, despite the structural trends and geochronological line of evidence [16]. The Paraná Basin in South America and Karoo Basin in Southern Africa have been correlated on the basis of geological, paleontological, and palaeoecological studies. Extensive continental glaciations covering both parts and sedimentary sequences in the two basins have been easily correlated due to very similar faunistic and floristic assemblages [8]. Margin basins from prolific hydrocarbon provinces with oil habitats have been correlated as indicated by paleogeographic ties [17]. More than five predicted matches have been validated between West African basins from Rio Muni (in Equatorial Guinea) to Angola and their Brazilian conjugate basins from Recôncavo to Santos, on the basis of oil geochemical family characterisation [18].

Most studies carried out to establish the pre-drift geological correlations between the two continents have been on the basis of the rock associations, tectonic links, geochronological data, mineralisation, and structural patterns, which are traceable on both continents $[2,3,5,10,19-24]$. None of these studies considered the use of continental argillaceous sediments, such as kaolins, in pre-drift reconstructions, despite kaolins being good paleoclimatic and paleoenvironmental indicators [25], with the exception of Petschnick et al. [26], which was limited to marine argillaceous sediments of the South Atlantic. Considering the enormous thick clay deposits, particularly kaolin deposits, occurring on both continents $[27,28]$, it is imperative to also correlate the clay deposits on both continents. Hitherto, there has never been any formal attempt to correlate these deposits, despite South America and Africa being joined until their breakup into separate continents during the Cretaceous period. Hence, there is still much uncertainty in correlations between the two continents as far as clay and clay minerals are concerned [10,29]. Africa and South America occupy strategic places in the global tectonic understanding and have attracted geoscientific interest since the beginning of studies on continental drift [2]. Therefore, the integration of available data will allow the re-evaluation of the geological framework of the two domains and provide new insights for correlations between them. This review is a comparative study on the mineralogical and geochemical characteristics of some West African and South American kaolins vis-à-vis their provenance and the paleoenvironmental conditions under which they were formed.

\section{Geologic Setting of the Selected Cretaceous Kaolin Deposits}

The studied Cretaceous deposits are the Lakiri and Eruku kaolins in Nigeria, the Logbaba and Yatchika kaolins in Cameroon, the soft Capim River kaolin in Brazil, and the Santa Cruz kaolin in Argentina. Their detailed geological characteristics are described in Oyebanjo et al. [30,31] for the Nigerian kaolins; Bukalo et al. [32,33] for the Cameroonian kaolins; Santos and Rossetti [34], and Sousa et al. [35] for the Brazilian kaolin; and Dominguez et al. [36,37], and Dondi et al. [38] for the Argentine kaolin. The Cretaceous kaolin deposits from Nigeria (Lakiri and Eruku) are located within the Ise Formation (Abeokuta Group) of the Eastern Dahomey Basin (Figure 1a). The Ise Formation overlying the Basement Complex consists of continental sands, grits, and siltstones with interbeds of kaolinitic clays as high as several metres in some places [30]. Furthermore, the Logbaba Formation of the Douala Sub-basin hosts the Logbaba and Yatchika kaolin deposits from Cameroon (Figure 1b). The Logbaba Formation is composed of sandstones and clays with intercalations of sands and the rare occurrence of limestones [32]. On the South American side, the soft Capim River kaolin deposit of the Cametá Sub-basin occurs within the Ipixuna Formation (Figure 1c), which consists of strongly deferruginised, kaolinised sandstones, and intercalated kaolinitic argillites [34]. The Santa Cruz kaolin deposits in Argentina occur within the Baquero Formation belonging to the Deseado Basin (Figure 1d). The Baquero Formation is a sequence of conglomerates and sandstones covered by dark grey clay (composed of kaolinite, quartz, and expandable clay minerals) with abundant inorganic carbon [37]. 

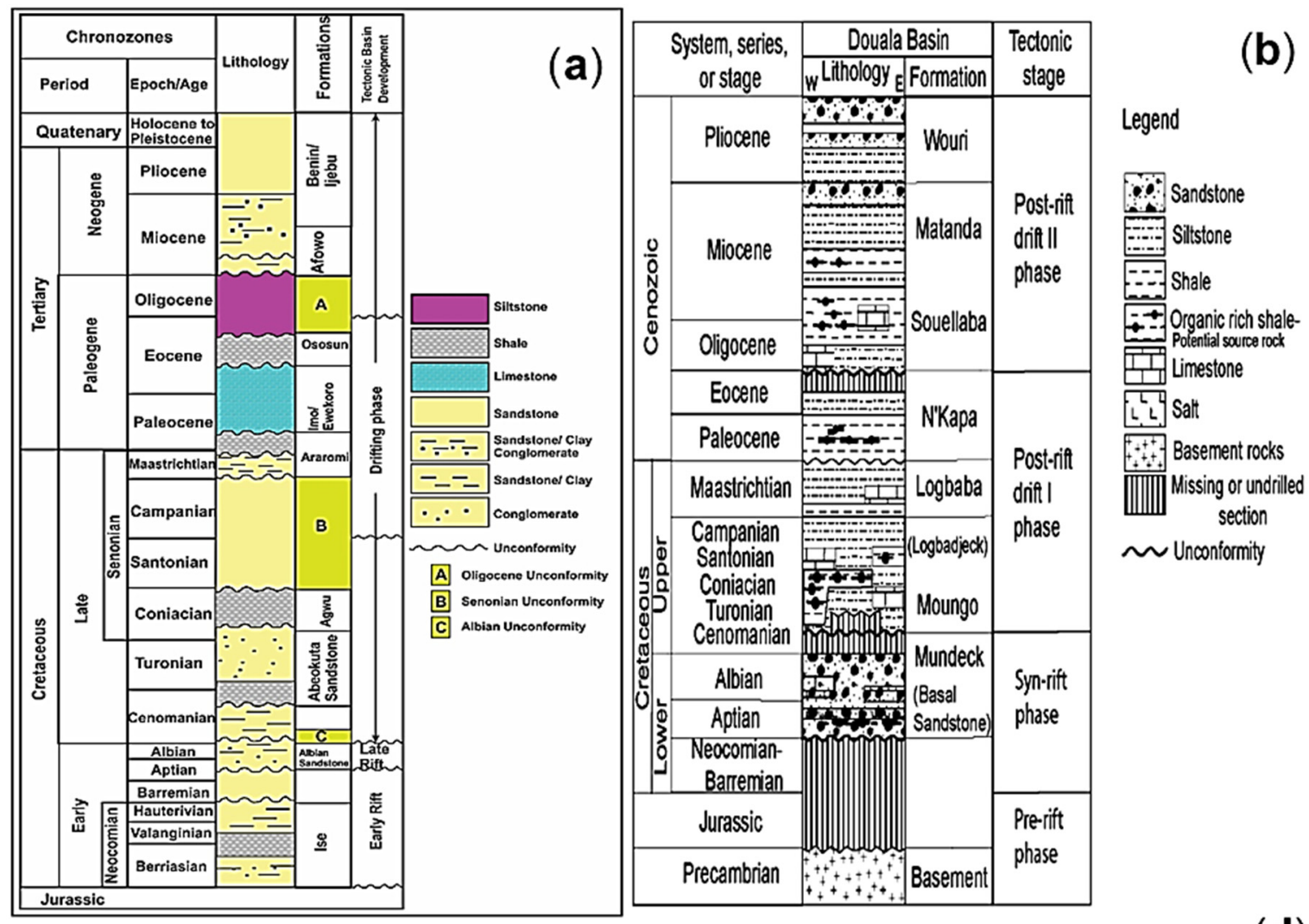

(c)
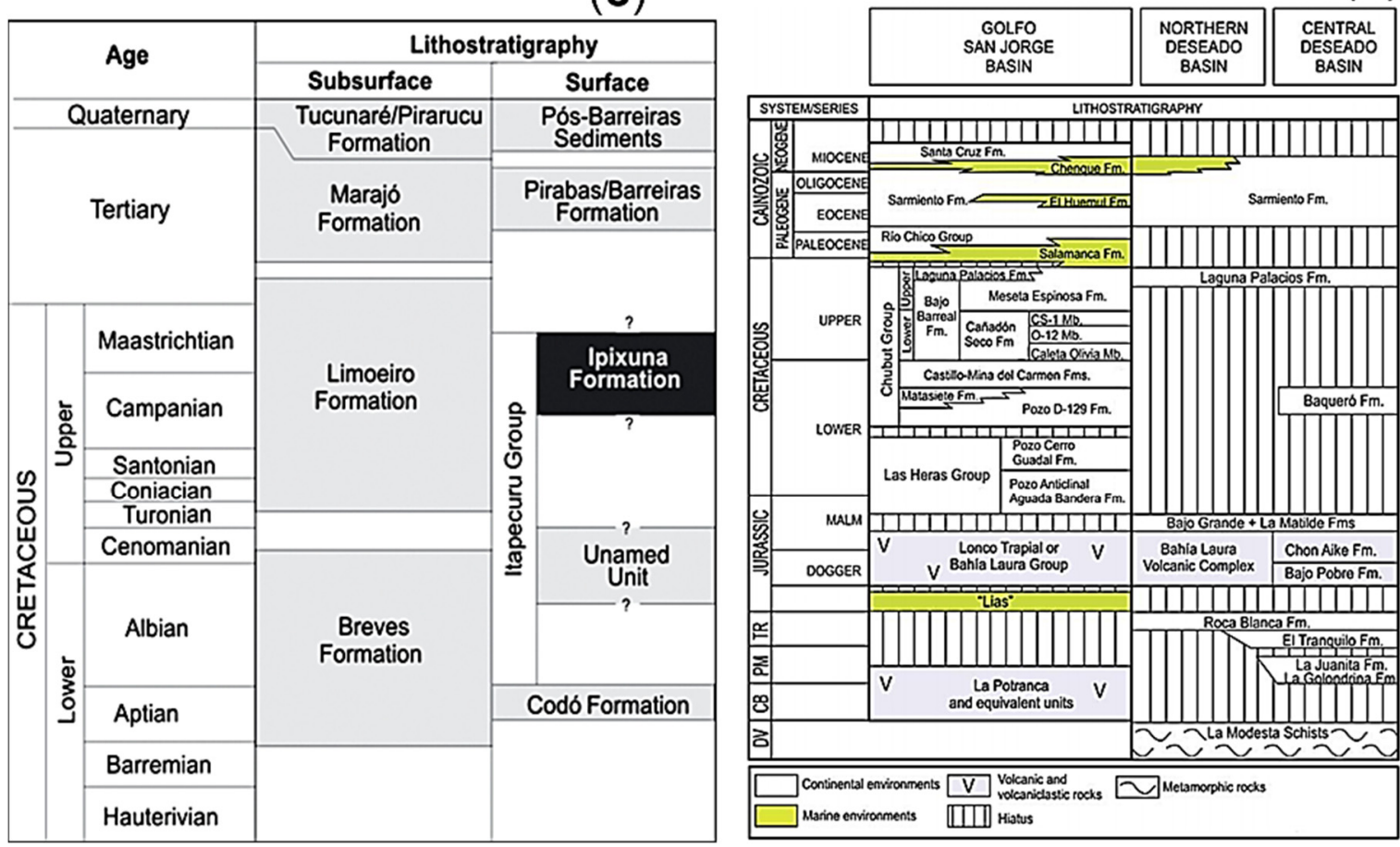

Figure 1. Generalised lithostratigraphy of (a) Eastern Dahomey Basin (modified from Olabode and Mohammed [39]), (b) Douala Sub-basin (after Anoh and Petters [40]), (c) Cameta Sub-basin (after Santos and Rossetti [34]), and (d) Deseado Basin (after Paredes et al. [41]). 


\section{Materials and Methods}

The mineralogical and geochemical data used in this study were obtained from 12 articles (Table 1). The list of selected Cretaceous kaolins from Africa and South America, and the various methods of analyses as stated by the respective authors are shown in Table 1. The various Cretaceous deposits were selected on the basis of their proximities to the continental margins, detrital origins, and availability of data.

Table 1. Selected Cretaceous kaolin deposits and summary of analytical methods used to determine their mineralogy and geochemistry.

\begin{tabular}{|c|c|c|c|c|c|}
\hline \multirow{2}{*}{ Country } & \multirow{2}{*}{ Deposits } & \multicolumn{3}{|c|}{ Methods } & \multirow{2}{*}{ References } \\
\hline & & Major/Trace Elements & Mineral Phases/Morphology & O/H Isotope & \\
\hline Nigeria & Lakiri Eruku & $\mathrm{XRF}^{1} / \mathrm{LAICPMS}^{2}$ & $\mathrm{XRD}^{3} / \mathrm{SEM}^{4}$ & FDXPMS $^{5}$ & {$[30,42-44]$} \\
\hline Cameroon & $\begin{array}{l}\text { Logbaba } \\
\text { Yatchika }\end{array}$ & $\mathrm{XRF}^{1} / \mathrm{ICPMS}^{6}$ & $\mathrm{XRD}^{3} / \mathrm{SEM}^{4}$ & FDXPMS 5 & [45-47] \\
\hline Argentina & Santa Cruz & $\mathrm{XRF}^{1} / \mathrm{INAA}^{7} / \mathrm{ICPOES}^{8}$ & $\mathrm{XRD}^{3} / \mathrm{SEM}^{4}$ & SVGID $^{9} /$ SS $^{10}$ & {$[36,37]$} \\
\hline Brazil & $\begin{array}{l}\text { Soft Capim } \\
\text { River }\end{array}$ & ICPAES $^{11} /$ ICPMS $^{7}$ & $\mathrm{XRD}^{3} / \mathrm{SEM}^{4}$ & $\begin{array}{c}\text { FMTDMS }^{12} / \\
\text { TFTCEA }^{13}\end{array}$ & {$[35,48,49]$} \\
\hline
\end{tabular}

${ }^{1}$ X-ray Fluorescence Spectroscopy, ${ }^{2}$ Laser Ablation Inductively Coupled Plasma Mass Spectrometry, ${ }^{3}$ X-ray Diffraction, ${ }^{4}$ Scanning Electron Microscopy, ${ }^{5}$ Finnegan DeltaXP mass spectrometry, ${ }^{6}$ Inductively Coupled Plasma Mass Spectrometry, ${ }^{7}$ Instrumental Neutron Activation Analysis, ${ }^{8}$ Inductively-Coupled Plasma Optical Emission Spectrometry, ${ }^{9}$ SIRA II-VG Isotech device, ${ }^{10}$ SIRA II spectrometry, ${ }^{11}$ Inductively Coupled Plasma Atomic Emission Spectroscopy, ${ }^{12}$ a Finnigan-MAT DELTA mass spectrometry, ${ }^{13}$ Thermo-Finnigan Thermal Conversion Elemental Analysis.

\section{Results and Discussion}

\subsection{Mineralogical Considerations}

\subsubsection{XRD Studies}

The Lakiri and soft Capim River kaolins contained greater amounts of kaolinite (averages of $99 \mathrm{wt} \%$ and $98 \mathrm{wt} \%$, respectively) and less quartz (average of $1 \mathrm{wt} \%$ for both), relative to other selected kaolins from Cameroon and Argentina (Table 2). However, the Logbaba, Yatchika, and Santa Cruz kaolin deposits had other clay minerals, such as illite/illite-smectite interstratified and smectite, occurring in them. In addition, titania and iron oxide minerals were present in all the kaolins in trace-to-minor percentages (Table 2).

The mineralogical characteristics of these kaolins will affect their potential industrial uses [49]. A plot of the average percentages of minerals present in each of the deposits is shown in the ternary diagram for the general mineralogical classification of economic kaolin deposits, which categorises the deposits according to kaolin types (Figure 2). The Lakiri and soft Capim River kaolins present higher average kaolinite abundances, plotted in the region of pure kaolin, whereas other kaolins (except Yatchika) have lower average kaolinite and higher quartz contents, plotted in the region of sandy kaolins.

The Hinckley index (HI) average values of 0.98 (Eruku kaolin), 0.99 (Lakiri kaolin), and 1.11 (soft Capim River kaolin) indicate a moderate kaolinite structural order, whereas the value of 0.40 for the Santa Cruz kaolin deposits indicates a poor kaolinite structural order. From the HI averages (Table 2), kaolins can be classified, in increasing order of kaolinite structural order, as follows: Santa Cruz kaolin (with the least orderliness) < Eruku kaolin < Lakiri kaolin < soft Capim River kaolin (with the best orderliness). 
Table 2. Average mineralogical compositions (wt\%) of the selected Cretaceous kaolin deposits. Ka: kaolinite; Qz: quartz; I/S: illite and illite-smectite interstratified; Sm: smectite; M: mica; Fd: feldspar; Ac: titania and iron oxide minerals; HI: Hinckley index.

\begin{tabular}{|c|c|c|c|c|c|c|c|c|c|}
\hline Country & Deposit & $\mathbf{K a}$ & $\mathrm{Qz}$ & $\mathrm{I} / \mathrm{S}$ & $\mathrm{Sm}$ & $\mathbf{M}$ & Fd & Ac & HI \\
\hline \multirow{2}{*}{ Nigeria } & Lakiri $^{1}$ & 99 & 1 & - & - & - & - & trace & $0.99^{a}$ \\
\hline & Eruku $^{1}$ & 78 & 16 & - & - & 4 & - & 2 & $0.98^{a}$ \\
\hline \multirow{2}{*}{ Cameroon } & Logbaba $^{2}$ & 48 & 41 & 2 & 5 & - & - & 4 & - \\
\hline & Yatchika $^{2}$ & 42 & 34 & 5 & 14 & - & - & 5 & - \\
\hline Argentina & Santa Cruz ${ }^{3}$ & 50 & 35 & 6 & 4 & - & 2 & 3 & 0.40 \\
\hline Brazil & Soft Capim River ${ }^{4}$ & 98 & 1 & - & - & - & - & 1 & $1.11^{b}$ \\
\hline
\end{tabular}

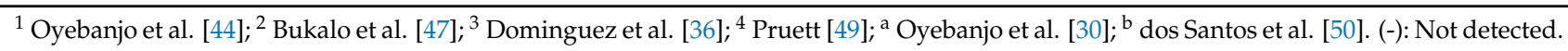

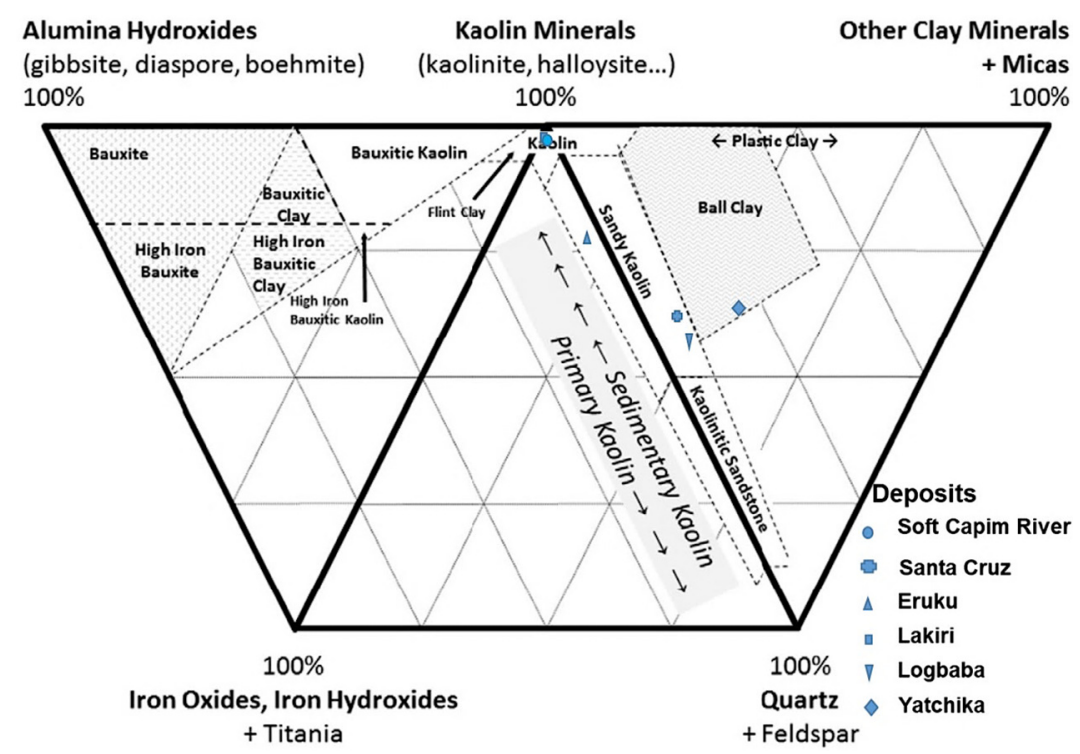

Figure 2. Mineralogical classification by kaolin type for the selected Cretaceous kaolins (fields after Pruett [49]).

\subsubsection{Kaolinite Crystal Habit}

The SEM images display the various crystal habits of the selected Cretaceous kaolins (Figures 3-5). Figures 3 and 4 show that all the studied kaolins have kaolinite crystals occurring as thin platy particles and pseudohexagonal plates (Figure 5).

In addition, the Nigerian and Cameroonian kaolins appear to have less microporosity between grains than what can be observed between grains in the Brazilian soft Capim River kaolins. This could be attributed to the coarser kaolinite with paucity of ultra-fine $(<0.1 \mu \mathrm{m})$ particles in the matrix between the stacks in the soft Capim River kaolin. The kaolinite plates in the Nigerian, Cameroonian, and Argentine kaolins have subhedral-anhedral external forms with irregular edges, whereas the soft Capim River kaolinite crystals are euhedral with smooth edges. 

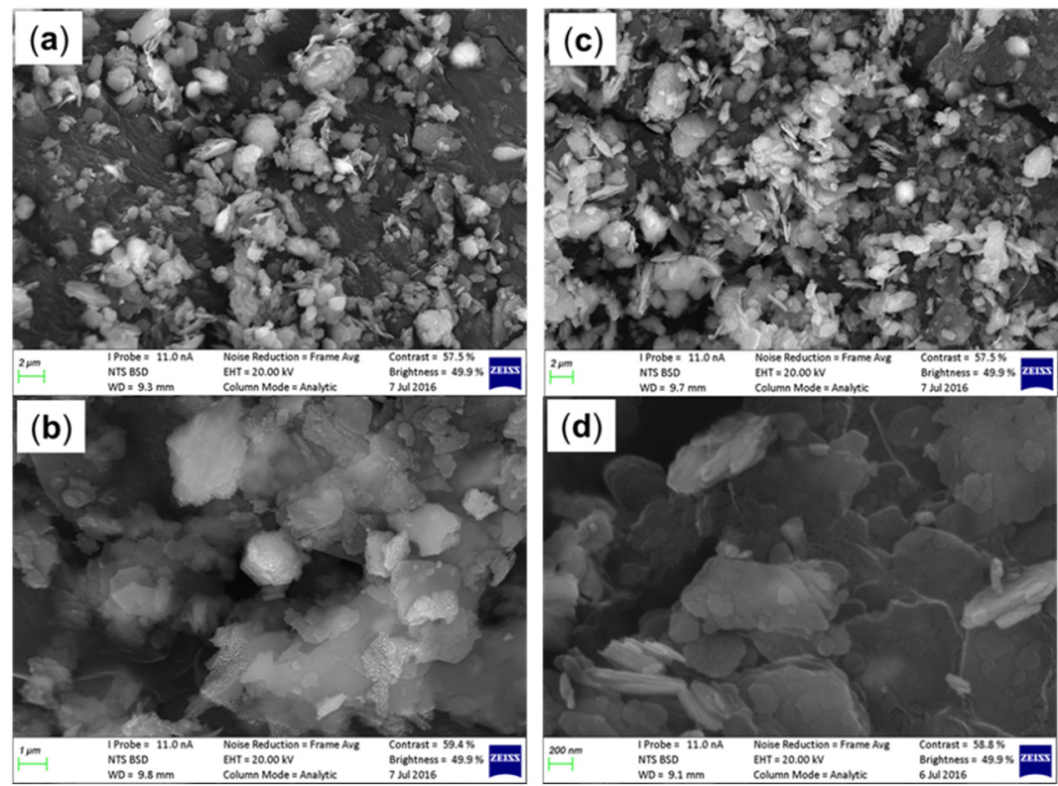

Figure 3. SEM micrographs of Cretaceous Eruku $(\mathbf{a}, \mathbf{b})$ and Lakiri kaolins $(\mathbf{c}, \mathbf{d})$ in Nigeria $[42,44]$.
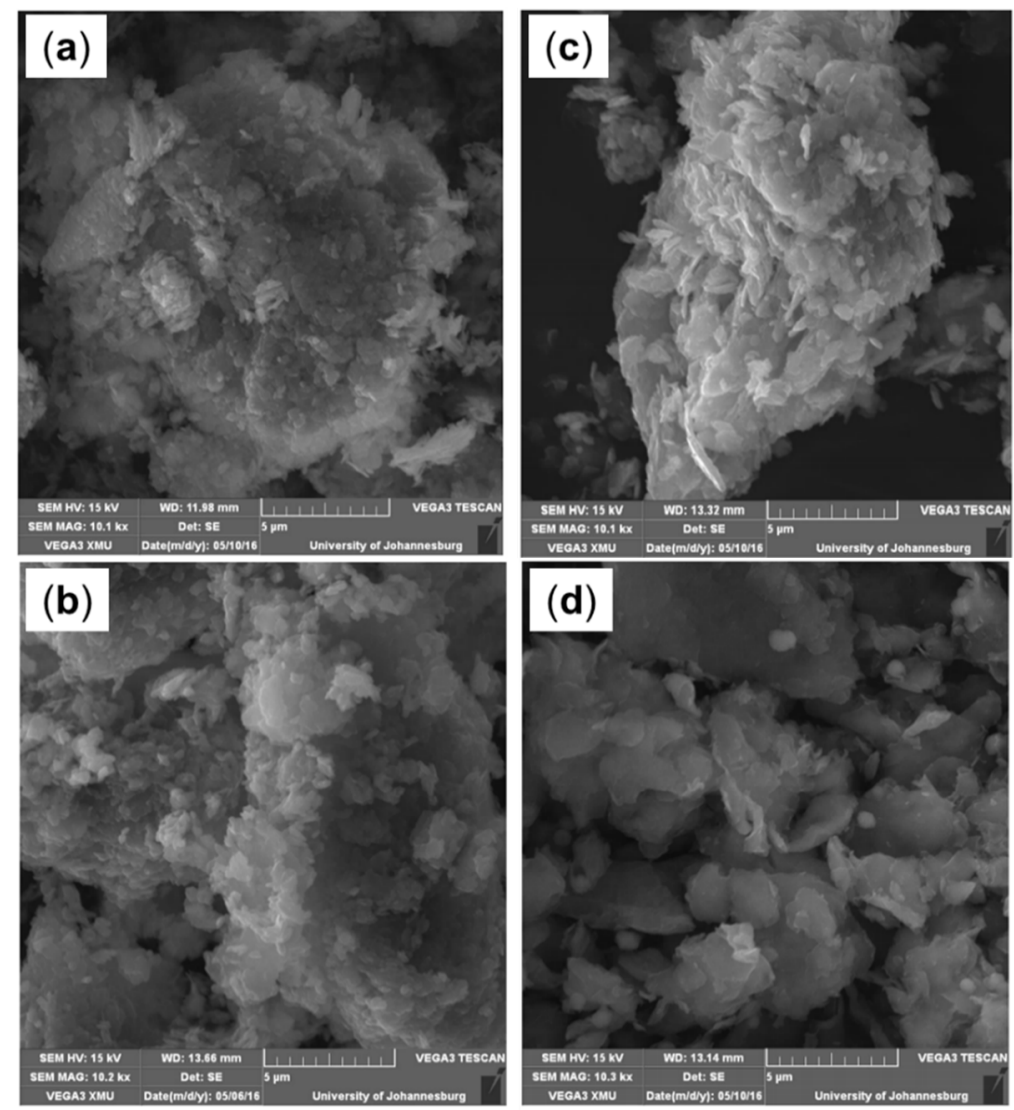

Figure 4. SEM micrographs of Cretaceous Logbaba $(\mathbf{a}, \mathbf{b})$ and Yatchika kaolins (c,d) in Cameroon [45]. 

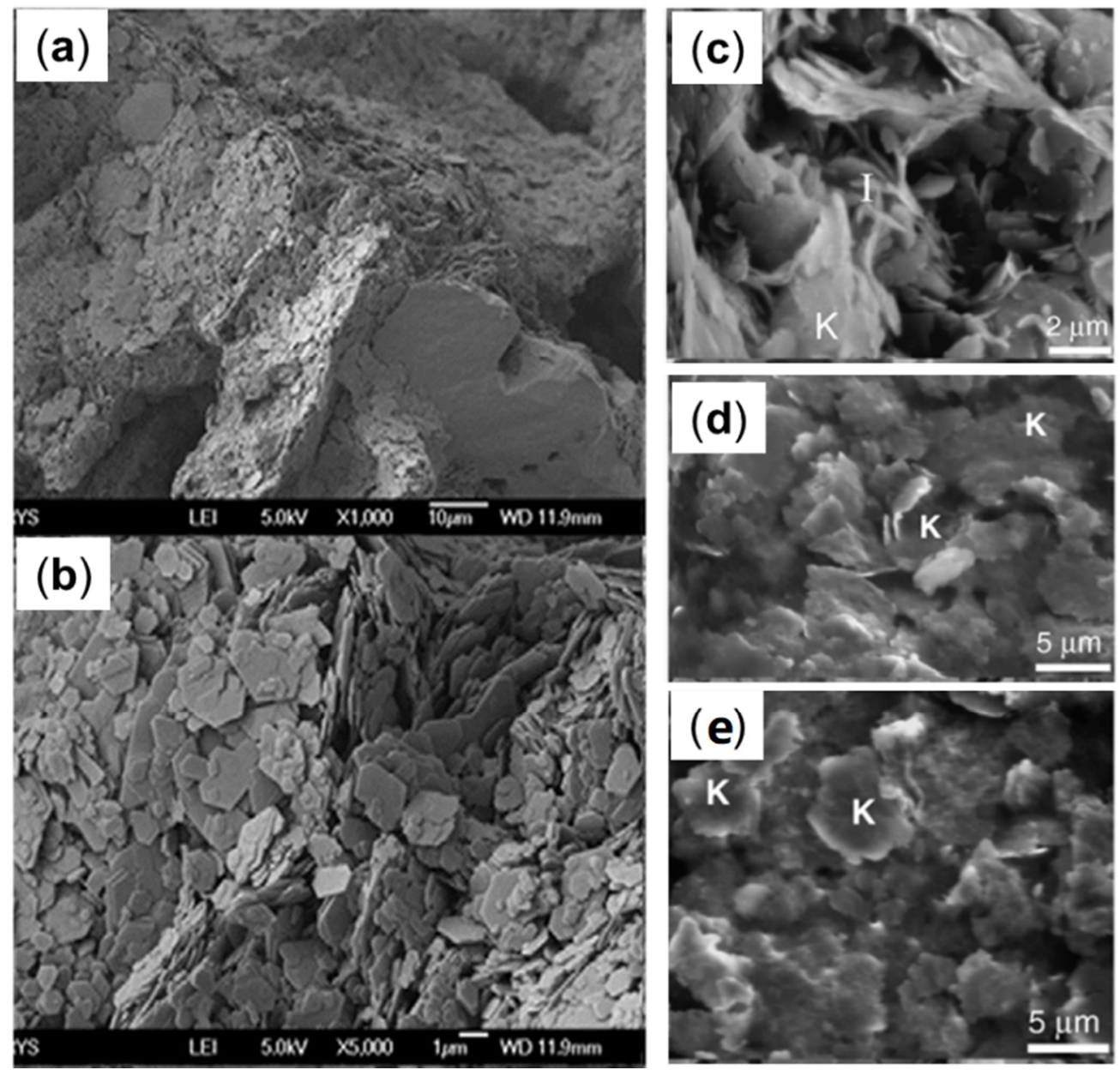

Figure 5. SEM micrographs of Cretaceous soft Capim River (a,b) and Santa Cruz kaolins (c-e) in Brazil [49] and Argentina [36], respectively.

\subsection{Geochemical Considerations}

The average $\mathrm{SiO}_{2}$ and $\mathrm{Al}_{2} \mathrm{O}_{3}$ contents showed variation among the kaolins as result of their kaolinite and quartz contents. The high $\mathrm{SiO}_{2} / \mathrm{Al}_{2} \mathrm{O}_{3}$ ratios for Eruku, Logbaba, Yatchika, and Santa Cruz kaolins relative to typical kaolinite (1.17) could be attributed to their higher percentages of quartz. The average $\mathrm{TiO}_{2}$ and $\mathrm{Fe}_{2} \mathrm{O}_{3}$ values for Nigerian and Cameroonian kaolins were higher than those obtained from Brazil and Argentina. Other oxides ( $\mathrm{MnO}, \mathrm{MgO}, \mathrm{CaO}, \mathrm{Na}_{2} \mathrm{O}, \mathrm{K}_{2} \mathrm{O}$, and $\mathrm{P}_{2} \mathrm{O}_{5}$ ) occur as minor constituents (Table 3).

In assessing the paleoweathering conditions, the average chemical index of alteration (CIA) value of the soft Capim River kaolin (99.75) was the highest, whereas the Yatchika (96.30) had the lowest value (Table 3). The $\mathrm{Al}_{2} \mathrm{O}_{3}-\left(\mathrm{CaO}^{*}+\mathrm{Na}_{2} \mathrm{O}\right)-\mathrm{K}_{2} \mathrm{O}(\mathrm{A}-\mathrm{CN}-\mathrm{K})$ ternary plot with CIA shows that the source rocks experienced intense chemical weathering under tropical climatic conditions, with all plotting in/close to the kaolinite field with high CIA values (Figure 6). The variations in the geochemical features, despite having similarly high CIA values, indicate the high maturity of the Cretaceous kaolins, with their parent rock characteristics playing a more significant role than the degree of weathering [51].

The provenance of the kaolins was predominantly from intermediate to felsic rocks on the basis of Roser and Korsch [52] discrimination diagrams (Figure 7). The higher ratios of $\mathrm{K}_{2} \mathrm{O} / \mathrm{Na}_{2} \mathrm{O}$ in the kaolins further depict the dominance of $\mathrm{K}$-feldspar over plagioclase feldspar (albite) in their respective source rocks (except for the soft Capim River kaolin), assuming that no post-depositional modifications had occurred. In addition, all kaolins were formed under passive continental tectonic settings (Figure 8). 
Table 3. Average concentrations of major element oxides (wt\%), CIA, and trace elemental ratios of the selected Cretaceous kaolin deposits.

\begin{tabular}{|c|c|c|c|c|c|c|}
\hline & \multicolumn{2}{|c|}{ Nigeria } & \multicolumn{2}{|c|}{ Cameroon } & \multirow{2}{*}{$\begin{array}{c}\text { Argentina } \\
\text { Santa Cruz } \\
\end{array}$} & \multirow{2}{*}{$\begin{array}{c}\text { Brazil } \\
\text { Soft Capim River }^{4}\end{array}$} \\
\hline & Lakiri ${ }^{1}$ & Eruku $^{1}$ & Logbaba $^{2}$ & Yatchika $^{2}$ & & \\
\hline $\mathrm{SiO}_{2}$ & 49.64 & 56.82 & 61.38 & 51.66 & 64.35 & 44.3 \\
\hline $\mathrm{TiO}_{2}$ & 1.60 & 2.10 & 2.35 & 1.70 & 0.55 & 0.44 \\
\hline $\mathrm{Al}_{2} \mathrm{O}_{3}$ & 35.55 & 28.25 & 29.65 & 28.21 & 22.51 & 39.35 \\
\hline $\mathrm{Fe}_{2} \mathrm{O}_{3}$ & 1.09 & 2.56 & 1.04 & 7.75 & 0.99 & 0.66 \\
\hline $\mathrm{CaO}$ & 0.02 & 0.02 & 0.04 & 0.03 & 0.25 & $<0.02$ \\
\hline $\mathrm{MgO}$ & - & 0.04 & 0.08 & 0.70 & 0.24 & 0.04 \\
\hline $\mathrm{MnO}$ & 0.01 & 0.01 & - & - & 0.01 & - \\
\hline $\mathrm{Na}_{2} \mathrm{O}$ & 0.02 & 0.02 & 0.02 & 0.06 & 0.09 & $<0.06$ \\
\hline $\mathrm{K}_{2} \mathrm{O}$ & 0.41 & 0.20 & 0.18 & 0.99 & 0.69 & 0.02 \\
\hline $\mathrm{P}_{2} \mathrm{O}_{5}$ & 0.06 & 0.11 & 0.18 & 0.12 & 0.03 & $<0.09$ \\
\hline LOI & 12.57 & 10.00 & 4.76 & 9.02 & 10.11 & 14.15 \\
\hline CIA & 99.22 & 98.38 & 99.18 & 96.30 & 96.85 & 99.75 \\
\hline $\mathrm{SiO}_{2} / \mathrm{Al}_{2} \mathrm{O}_{3}$ & 1.40 & 2.01 & 2.07 & 1.83 & 2.86 & 1.13 \\
\hline $\mathrm{K}_{2} \mathrm{O} / \mathrm{Na}_{2} \mathrm{O}$ & 20.50 & 10.00 & 9.00 & 16.50 & 7.67 & - \\
\hline $\mathrm{V} / \mathrm{Cr}$ & 1.04 & 0.96 & 0.90 & 1.38 & 2.97 & 1.04 \\
\hline $\mathrm{Ni} / \mathrm{Co}$ & 7.88 & 5.52 & 2.95 & 7.21 & 1.97 & 8.37 \\
\hline
\end{tabular}

${ }^{1}$ Oyebanjo [42], ${ }^{2}$ Bukalo et al. [47], ${ }^{3}$ Dominguez et al. [36], ${ }^{4}$ dos Santos et al. [50]. (-): Not detected.

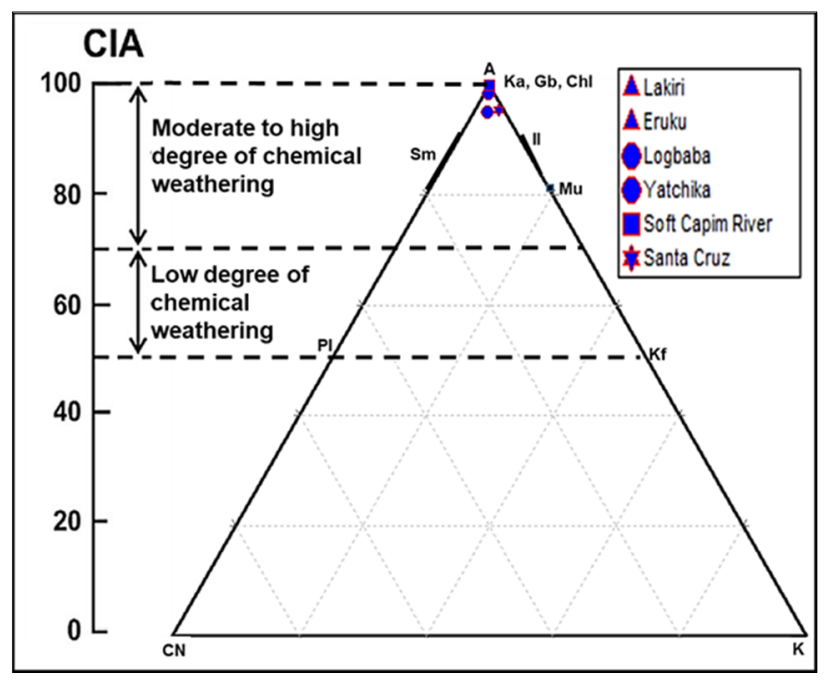

Figure 6. $\mathrm{A}-\mathrm{CN}-\mathrm{K}\left(\mathrm{Al}_{2} \mathrm{O}_{3}-\mathrm{CaO}^{*}+\mathrm{Na}_{2} \mathrm{O}-\mathrm{K}_{2} \mathrm{O}\right)$ ternary diagram of the selected Cretaceous kaolins combined with CIA (fields after Nesbitt and Young [53], and Hofer et al. [54]).

In evaluating the paleoredox conditions under which the kaolins were formed, $\mathrm{Ni} / \mathrm{Co}$ ratios greater than five represent suboxic and anoxic environments, whereas ratios less than five suggest oxic environments [55]. Gross [56] and Landergreen and Manhem [57] obtained $\mathrm{V} / \mathrm{Cr}$ ratios of 1.1 and 0.75 , respectively, for anoxic recent marine sediments to brackishwater sediments and higher values between 2 and 10 for oxic environments. The average $\mathrm{Ni} / \mathrm{Co}$ ratios obtained for the Cretaceous kaolins suggests that they were deposited in anoxic environments (except for the Logbaba and Santa Cruz kaolins, which were deposited in oxic environments) (Table 3 ).

This is also confirmed by the $\mathrm{V} / \mathrm{Cr}$ ratios, which indicated deposition in anoxic environments for all kaolins, except for the Santa Cruz kaolin, which was deposited in an oxic environment (Table 3). The observation that some of the kaolins were formed in a restricted oxygen-poor (anoxic) depositional environment is consistent with the horstand-graben structural systems for the Eastern Dahomey Basin [58,59] in Nigeria, the KribiCampo Sub-basin [60] in Cameroon, and the Cametá Sub-basin [35] in Brazil. 


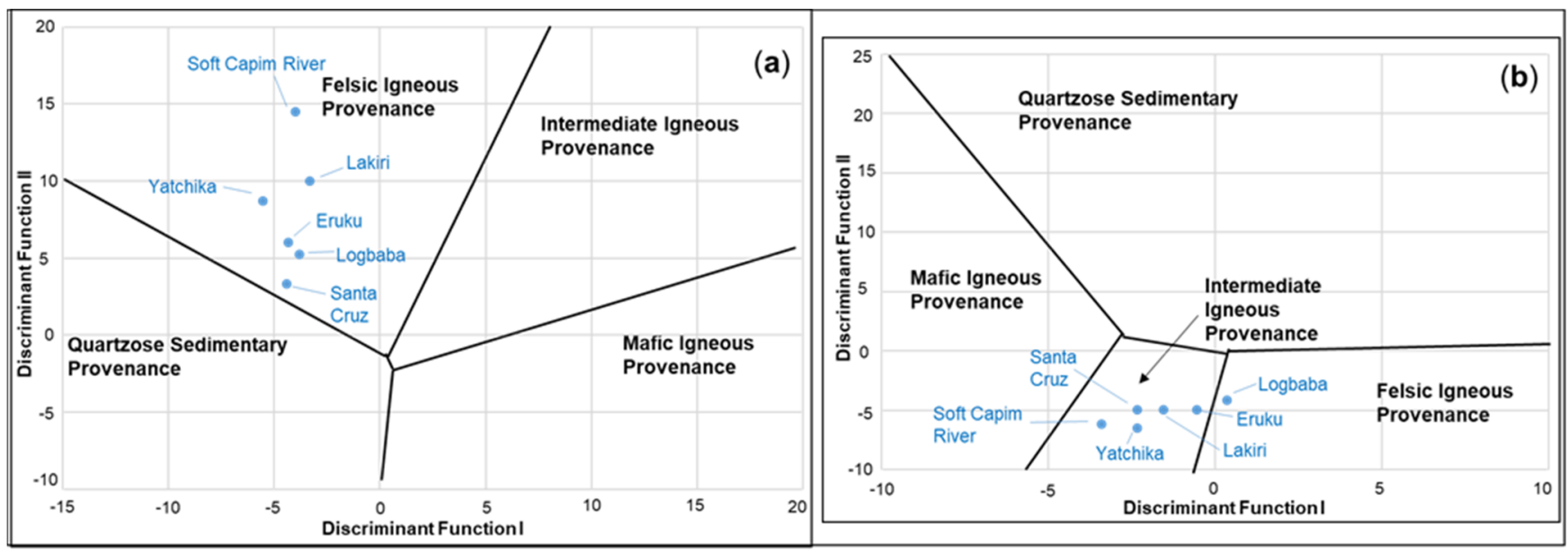

Figure 7. Discrimination diagrams for the provenance of the studied Cretaceous kaolin deposits using (a) raw major oxide concentrations-DFI $=0.445 \mathrm{TiO}_{2}+0.070 \mathrm{Al}_{2} \mathrm{O}_{3}-0.250 \mathrm{Fe}_{2} \mathrm{O}_{3}-1.142 \mathrm{MgO}+0.438 \mathrm{CaO}+1.475 \mathrm{Na}_{2} \mathrm{O}+1.426 \mathrm{~K}_{2} \mathrm{O}-$ 6.861 and DFII $=-1.773 \mathrm{TiO}_{2}+0.607 \mathrm{Al}_{2} \mathrm{O}_{3}+0.760 \mathrm{Fe}_{2} \mathrm{O}_{3}-1.500 \mathrm{MgO}+0.616 \mathrm{CaO}+0.509 \mathrm{Na}_{2} \mathrm{O}-1.224 \mathrm{~K}_{2} \mathrm{O}-9.090$; and (b) ratios of major oxides to $\mathrm{Al}_{2} \mathrm{O}_{3}-\mathrm{DFI}=56.500 \mathrm{TiO}_{2} / \mathrm{Al}_{2} \mathrm{O}_{3}-10.879 \mathrm{Fe}_{2} \mathrm{O}_{3} / \mathrm{Al}_{2} \mathrm{O}_{3}+30.875 \mathrm{MgO} / \mathrm{Al}_{2} \mathrm{O}_{3}-5.404$ $\mathrm{Na}_{2} \mathrm{O} / \mathrm{Al}_{2} \mathrm{O}_{3}+11.112 \mathrm{~K} 2 \mathrm{O} / \mathrm{Al}_{2} \mathrm{O}_{3}-3.89$ and DFII $=30.638 \mathrm{TiO}_{2} / \mathrm{Al}_{2} \mathrm{O}_{3}-12.541 \mathrm{Fe}_{2} \mathrm{O}_{3} / \mathrm{Al}_{2} \mathrm{O}_{3}+7.329 \mathrm{MgO} / \mathrm{Al}_{2} \mathrm{O}_{3}+$ $12.031 \mathrm{Na}_{2} \mathrm{O} / \mathrm{Al}_{2} \mathrm{O}_{3}+35.402 \mathrm{~K}_{2} \mathrm{O} / \mathrm{Al}_{2} \mathrm{O}_{3}-6.382$ (fields after Roser and Korsch [52]).

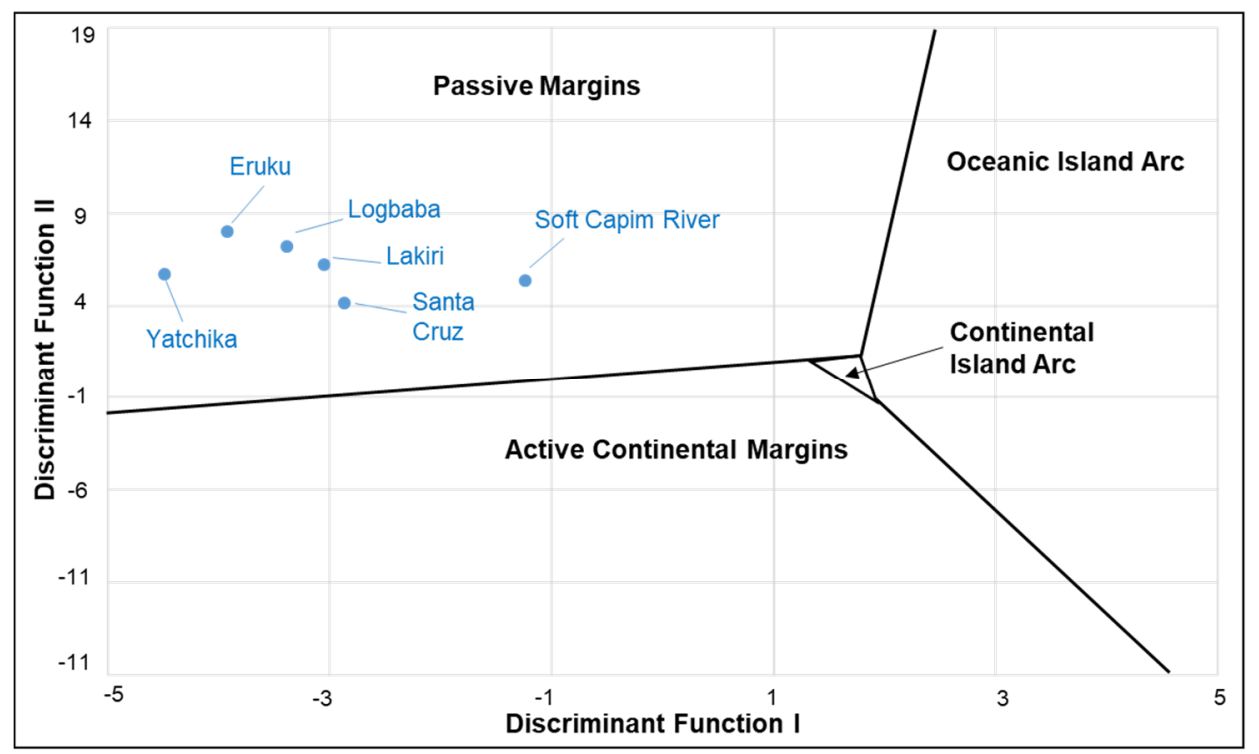

Figure 8. Discrimination function diagram for sedimentary tectonic settings of the $<2 \mu \mathrm{m}$ fractions of the studied kaolin deposits (fields after Bhatia [61]). DFI $=-0.0447 \mathrm{SiO}_{2}-0.972 \mathrm{TiO}_{2}+0.008 \mathrm{Al}_{2} \mathrm{O}_{3}-0.267 \mathrm{Fe}_{2} \mathrm{O}_{3}+0.208 \mathrm{FeO}-3.082 \mathrm{MnO}+$ $0.140 \mathrm{MgO}+0.195 \mathrm{CaO}+0.719 \mathrm{Na}_{2} \mathrm{O}-0.032 \mathrm{~K}_{2} \mathrm{O}+7.510 \mathrm{P}_{2} \mathrm{O}_{5}+0.303$ and $\mathrm{DFII}=-0.421 \mathrm{SiO}_{2}+1.998 \mathrm{TiO}_{2}-0.526 \mathrm{Al}_{2} \mathrm{O}_{3}-$ $0.551 \mathrm{Fe}_{2} \mathrm{O}_{3}-1.610 \mathrm{FeO}+2.720 \mathrm{MnO}+0.881 \mathrm{MgO}-0.907 \mathrm{CaO}-0.177 \mathrm{Na}_{2} \mathrm{O}-1.840 \mathrm{~K}_{2} \mathrm{O}+7.244 \mathrm{P}_{2} \mathrm{O}_{5}+43.57$.

\subsection{Hydrogen and Oxygen Stable Isotopic Considerations}

The average hydrogen and oxygen compositions of the selected Cretaceous kaolins from Nigeria, Cameroon, Brazil, and Argentina are presented in Table 4 and plotted in Figure 9. The average $\delta^{18} \mathrm{O}$ values obtained for all studied Cretaceous kaolins were within the +19 and $+23 \%$ values for kaolinites of sedimentary origin, except for the Brazil soft Capim River kaolin that presented a value of $15.65 \%$, which corresponds to kaolinites from residual deposits with $\delta^{18} \mathrm{O}$ values between +15 and $+19 \%$ [62] (Table 4). dos Santos et al. [48] attributed the low $\delta^{18} \mathrm{O}$ of the soft Capim River kaolin to mineralogical contaminations from framework grains, rather than post-formational modifications due 
to interactions with meteoric waters depleted in $\delta^{18} \mathrm{O}$. They further concluded that the $\delta^{18} \mathrm{O}$ values reflect a low isotopic composition of the parent minerals, such as feldspars and micas with variable rates of replacements by kaolinites.

Table 4. Average $\delta^{18} \mathrm{O}$ and $\delta \mathrm{D}$ values (in \%o) and calculated temperature of kaolinisation (in ${ }^{\circ} \mathrm{C}$ ) for the selected Cretaceous kaolins.

\begin{tabular}{ccccc}
\hline Country & Deposit & $\boldsymbol{\delta}^{\mathbf{1 8}} \mathbf{O}$ & $\boldsymbol{\delta} \mathbf{D}$ & Temperature \\
\hline \multirow{2}{*}{ Nigeria } & Eruku $^{1}$ & 19.2 & -53 & 31.2 \\
\cline { 2 - 5 } & Lakiri $^{1}$ & 19.7 & -52 & 29.9 \\
\hline \multirow{2}{*}{ Cameroon } & Logbaba $^{2}$ & 20.2 & -64 & 20.82 \\
\cline { 2 - 5 } & Yatchika $^{2}$ & 19.4 & -66 & 22.88 \\
\hline \multirow{2}{*}{ Argentina } & Santa Cruz $^{3}$ & 19.6 & -103 & 4.87 \\
\hline Brazil & soft Capim River $^{4}$ & 15.7 & -69 & 38.4 \\
\hline
\end{tabular}

${ }^{1}$ Oyebanjo et al. [43]; ${ }^{2}$ Bukalo et al. [46]; ${ }^{3}$ Dominguez et al. [37]; ${ }^{4}$ dos Santos et al. [48].

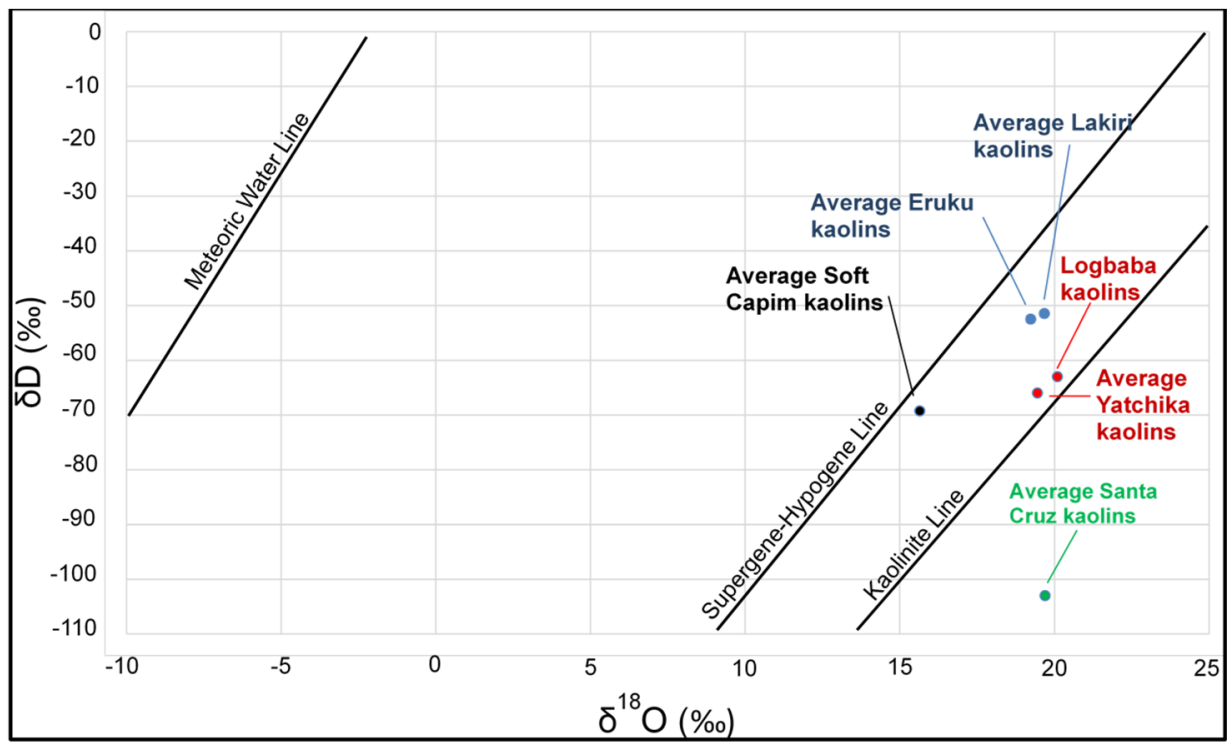

Figure 9. Average $\delta \mathrm{D}$ versus $\delta^{18} \mathrm{O}$ isotopic composition diagram of the selected Cretaceous kaolins.

The Nigerian kaolins had the highest average $\delta \mathrm{D}$ values followed by the Cameroonian kaolins relative to the Brazilian soft Capim River and the Argentine kaolins. This suggests that the isotopic composition of meteoric water during the formation of the Nigerian kaolins was heavier, whereas the other kaolins might have interacted with paleometeoric waters with lesser levels of $\delta^{18} \mathrm{O}$ and $\delta \mathrm{D}$ [63]. Figure 9 shows that the average $\delta^{18} \mathrm{O}$ and $\delta \mathrm{D}$ values of the selected Cretaceous kaolins are plotted between the kaolinite line (KL) of Savin and Epstein [64] and the supergene-hypogene line (SHL) of Sheppard et al. [65], except for the Santa Cruz kaolin deposits, which are plotted to the right of the KL. The position of the Santa Cruz kaolin deposits below the KL is suggestive of post-formational modifications of the isotopic compositions of the Argentine kaolinites [66,67]. The plot of (Ba $+\mathrm{Sr}$ ) versus $(\mathrm{Ce}+\mathrm{Y}+\mathrm{La})[68]$ also indicates supergene kaolinisation mechanisms for the kaolins (Figure 10). 


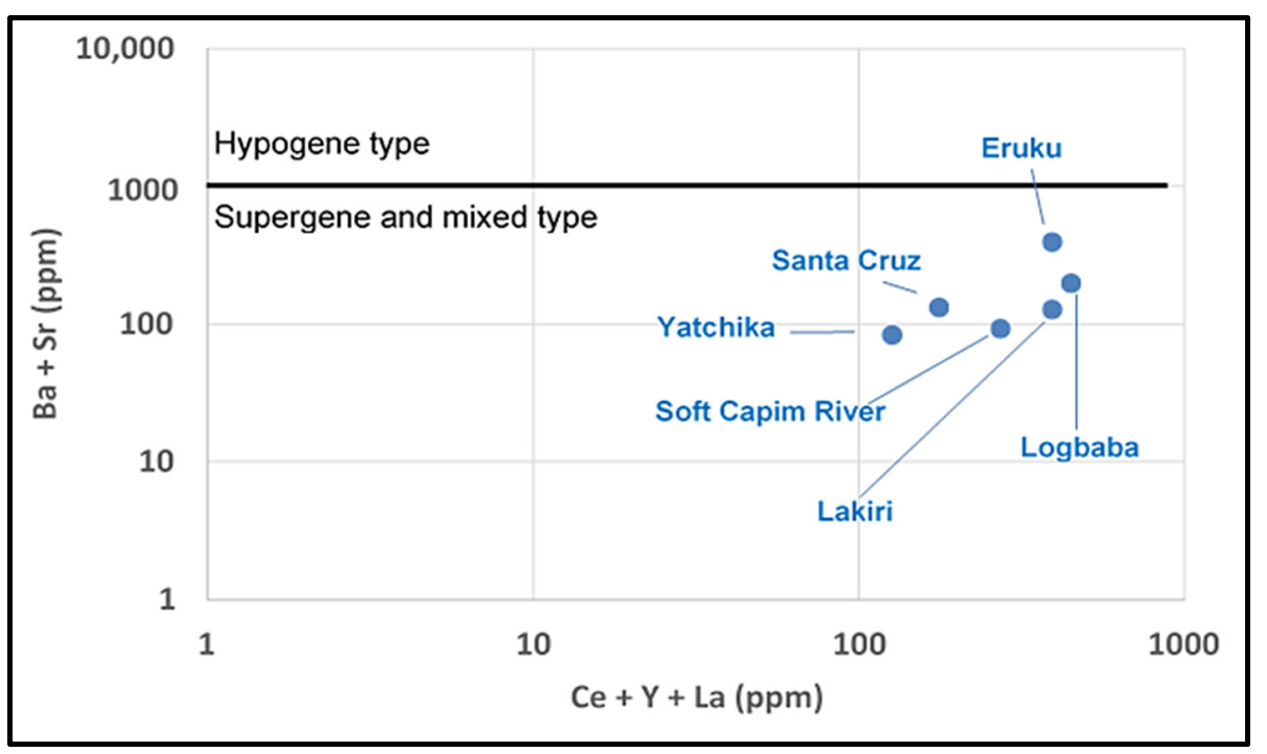

Figure 10. $\mathrm{Ba}+\mathrm{Sr}$ versus $\mathrm{Ce}+\mathrm{Y}+$ La binary discrimination diagram of the selected Cretaceous kaolins (fields after Dill et al. [68]).

The calculated average temperatures of kaolinisation $\left(T_{\mathcal{C}}\right)$ for the selected Cretaceous kaolins using the Clauer et al. [69] and Galan et al. [70] equations are given in Table 4. The average $T_{c}$ for the Nigerian and Cameroonian kaolins was lower than the values obtained for the Brazilian soft Capim River kaolin. However, the average $T_{c}$ values obtained for both the Nigerian and Brazilian kaolins suggest that the kaolins were formed under warm conditions, whereas the average $\mathrm{T}_{\mathrm{c}}$ of $21.85^{\circ} \mathrm{C}$ of the Cameroonian kaolins suggests formation under cooler conditions. The low / inaccurate $T_{c}$ for the Argentine kaolin could be attributed to the post-formational modifications of the isotopic compositions of the kaolinite due to their interaction with meteoric water depleted in $\delta^{18} \mathrm{O}$ and $\delta \mathrm{D}[63,67]$. It is noteworthy that the $\mathrm{T}_{\mathrm{c}}$ values below $50{ }^{\circ} \mathrm{C}$ do not relate kaolinisation with a lowtemperature hydrothermal event [69]. The average paleotemperatures obtained for the Nigerian, Cameroonian, and Brazilian kaolins were characteristic of paleoweathering formation under tropical climates. Previous work by Scotese [71] concluded that the three countries had identical tropical climates during the Cretaceous Period.

\section{Conclusions}

Selected Cretaceous African (Lakiri and Eruku in Nigeria, and Logbaba and Yatchika in Cameroon) and South American (soft Capim River in Brazil and Santa Cruz in Argentina) kaolins were studied to determine similarities and differences in their provenance and paleoenvironment. On the basis of their mineral phases, Lakiri and soft Capim River kaolins were pure, showing moderate kaolinite structural order, unlike the other kaolins. Morphologically, kaolinite crystals in all the kaolin samples generally occurred as thin platy particles and pseudohexagonal plates, although the African kaolins contained less microporosity between their crystals. From their geochemical characteristics, all the kaolins displayed the extreme silicate weathering of intermediate to felsic rocks that are formed under passive continental tectonic settings. The Nigerian, Cameroonian, and Brazilian kaolins were formed under anoxic paleoredox conditions, whereas the Argentine kaolin was formed under oxic paleoredox conditions. However, all the kaolins were formed under supergene conditions in a tropical climate. This review shows that there are more similarities between Cretaceous African and South American kaolins than previously considered, thereby positively correlating the two continental masses. 
Author Contributions: Conceptualisation, O.O., N.B. and G.-I.E.; formal analysis, O.O., N.B. and G.-I.E.; funding acquisition, G.-I.E.; investigation, O.O. and N.B.; writing-original draft preparation, O.O. and N.B.; writing-review and editing, G.-I.E.; supervision, G.-I.E. All authors have read and agreed to the published version of the manuscript.

Funding: This research was funded by the NATIONAL RESEARCH FOUNDATION (South Africa), grant number UID 91559, 2014-2016. The APC was funded by the University of Venda.

Acknowledgments: In this section, you can acknowledge any support given which is not covered by the author contribution or funding sections. This may include administrative and technical support, or donations in kind (e.g., materials used for experiments).

Conflicts of Interest: The authors declare no conflict of interest.

\section{References}

1. Carey, S.W. The Tectonic Approach to Continental Drift. In Proceedings of the Continental Drift: A Symposium, Hobart, Australia, 6-9 March 1956; Geology Department of the University of Tasmania: Hobart, Australia, 1958; pp. 177-355.

2. Torquato, J.R.; Cordani, U.G. Brazil-Africa Geological Links. Earth-Sci. Rev. 1981, 17, 155-176. [CrossRef]

3. Cordani, U.G.; Fraga, L.M.; Reis, N.; Tassinari, C.C.; Brito-Neves, B.B. On the Origin and Tectonic Significance of the Intra-Plate Events of Grenvillian-Type Age in South America: A Discussion. J. S. Am. Earth Sci. 2010, 29, 143-159. [CrossRef]

4. du Toit, A.L. Land Connections between the Other Continents and South Africa in the Past. S. Afr. J. Sci. 1921, 18, 120-140.

5. du Toit, A.L. Our Wandering Continents: An Hypothesis of Continental Drifting; Oliver and Boyd: Edinburgh, UK, 1937.

6. Bullard, E.; Everett, J.E.; Gilbert Smith, A. The Fit of the Continents around the Atlantic. Philos. Trans. R. Soc. Lond. Ser. A Math. Phys. Sci. 1965, 258, 41-51. [CrossRef]

7. Allard, G.O.; Hurst, V.J. Brazil-Gabon Geologic Link Supports Continental Drift. Science 1969, 163, 528-532. [CrossRef]

8. Colbert, E.H. Continental drift and the distributions of fossil reptiles. In Implications of Continental Drift for the Earth Sciences; Tailing, D.H., Runcorn, S.K., Eds.; Academic Press: London, UK, 1973; pp. 395-412.

9. Rogers, J.J.; Santosh, M. Continents and Supercontinents; Oxford University Press: Oxford, UK, 2004; ISBN 0-19-534733-1.

10. Ernst, R.E.; Bleeker, W.; Söderlund, U.; Kerr, A.C. Large Igneous Provinces and Supercontinents: Toward Completing the Plate Tectonic Revolution. Lithos 2013, 174, 1-14. [CrossRef]

11. Hurley, P.M.; Rand, J.R.; Pinson, W.H.; Fairbairn, H.W.; de Almeida, F.F.M.; Melcher, G.C.; Cordani, U.G.; Kawashita, K.; Vandoros, P. Test of Continental Drift by Comparison of Radiometric Ages: A Pre-Drift Reconstruction Shows Matching Geologic Age Provinces in West Africa and Northern Brazil. Science 1967, 157, 495-500. [CrossRef]

12. De Almeida, F.F.M.; Amaral, G.; Cordani, U.; Kawashita, K. The Precambrian evolution of the South American cratonic margin south of the Amazon River. In The South Atlantic; Springer: Boston, MA, USA, 1973; pp. 411-446.

13. Torquato, J.R. Geotectonic Correlation between SE Brazil and SW Africa. An. Acad. Bras. Ciências 1976, 48, 353-363.

14. Guadagnin, F.; Chemale, F.; Magalhães, A.J.C.; Santana, A.; Dussin, I.; Takehara, L. Age Constraints on Crystal-Tuff from the Espinhaço Supergroup-Insight into the Paleoproterozoic to Mesoproterozoic Intracratonic Basin Cycles of the Congo-São Francisco Craton. Gondwana Res. 2015, 27, 363-376. [CrossRef]

15. Tugarinov, A. Geochronology of West Africa and Northeast Brazil. Geokhimiya 1967, 11, 1336-1349.

16. Almeida, F. de Precambrian Geology of Northeastern Brazil and Western Africa and the Theory of Continental Drift. Nat. Resour. Res. 1968, 4, 151-162.

17. Schiefelbein, C.; Zumberge, J.; Cameron, N.; Brown, S. Geochemical comparison of crude oil, South Atlantic Margins. In Petroleum Systems of the South Atlantic Margin; Mello, M., Katz, B., Eds.; AAPG Memoir; Geological Society: London, UK, 2000; Volume 73, pp. 15-26.

18. Schiefelbein, C.F.; Dickson, W.G.; Odegard, M.E.; Brooks, J. South Atlantic Margin Basin Analysis Using a G3 Approach (Geophysical, Geological and Geochemical). In Proceedings of the 8th International Congress of the Brazilian Geophysical Society and 5th Latin American Geophysical Conference, Rio de Janeiro, Brazil, 14-18 September 2003; European Association of Geoscientists \& Engineers: Houten, The Netherlands, 2003.

19. Caby, R. Precambrian Terranes of Benin-Nigeria and Northeast Brazil and the Late Proterozoic South Atlantic Fit. In Terranes in the Circum-Atlantic Paleozoic Orogens; Geological Society of America: Boulder, CO, USA, 1989; Volume 230, pp. 145-158.

20. Castaing, C.; Feybesse, J.L.; Thiéblemont, D.; Triboulet, C.; Chevremont, P. Palaeogeographical Reconstructions of the PanAfrican/Brasiliano Orogen: Closure of an Oceanic Domain or Intracontinental Convergence between Major Blocks? Precambrian Res. 1994, 69, 327-344. [CrossRef]

21. Trompette, R. Neoproterozoic ( 600 Ma) Aggregation of Western Gondwana: A Tentative Scenario. Precambrian Res. 1997, 82, 101-112. [CrossRef]

22. Neves, S.P. Proterozoic History of the Borborema Province (NE Brazil): Correlations with Neighboring Cratons and Pan-African Belts and Implications for the Evolution of Western Gondwana. Tectonics 2003, 22, 1031. [CrossRef]

23. De Oliveira Chaves, A.; Neves, J.M.C. Radiometric Ages, Aeromagnetic Expression, and General Geology of Mafic Dykes from Southeastern Brazil and Implications for African-South American Correlations. J. S. Am. Earth Sci. 2005, 19, 387-397. [CrossRef] 
24. Dickson, W.; Schiefelbein, C.; Zumberge, J.; Odegard, M. Basin Analysis in Brazilian and West African Conjugates: Combining Disciplines to Deconstruct Petroleum Systems. In Proceedings of the 25th Annual Gulf Coast SEPM Foundation Bob F. Perkins Research Conference, Houston, TX, USA, 4-7 December 2005. [CrossRef]

25. Tabor, N.J.; Montanez, I.P.; Southard, R.J. Paleoenvironmental Reconstruction from Chemical and Isotopic Compositions of Permo-Pennsylvanian Pedogenic Minerals. Geochim. Cosmochim. Acta 2002, 66, 3093-3107. [CrossRef]

26. Petschick, R.; Kuhn, G.; Gingele, F. Clay Mineral Distribution in Surface Sediments of the South Atlantic: Sources, Transport, and Relation to Oceanography. Mar. Geol. 1996, 130, 203-229. [CrossRef]

27. Tardy, Y.; Kobilsek, B.; Paquet, H. Mineralogical Composition and Geographical Distribution of African and Brazilian Periatlantic Laterites. The Influence of Continental Drift and Tropical Paleoclimates during the Past 150 Million Years and Implications for India and Australia. J. Afr. Earth Sci. 1991, 12, 283-295. [CrossRef]

28. Ekosse, G.-I.E. Kaolin Deposits and Occurrences in Africa: Geology, Mineralogy and Utilization. Appl. Clay Sci. 2010, 50, $212-236$. [CrossRef]

29. Pankhurst, R.J.; Trouw, R.; Brito-Neves, B.B.; Wits, M. West Gondwana: Pre-Cenozoic Correlations across the South Atlantic Region; Special Publications; Geological Society of London: London, UK, 2008; ISBN 1-86239-247-1.

30. Oyebanjo, O.M.; Ekosse, G.E.; Odiyo, J.O. Mineral Constituents and Kaolinite Crystallinity of the $<2$ Mm Fraction of CretaceousPaleogene/Neogene Kaolins from Eastern Dahomey and Niger Delta Basins, Nigeria. Open Geosci. 2018, 10, 157-166. [CrossRef]

31. Oyebanjo, O.; Ekosse, G.-I.; Odiyo, J. Geochemical Characterisation of the <2 Mm Fractions of Cretaceous-Tertiary Kaolins from Eastern Dahomey and Niger Delta Basins, Nigeria: Implications on Paleoenvironment, Provenance, and Tectonic Settings. J. Afr. Earth Sci. 2018, 147, 402-410. [CrossRef]

32. Bukalo, N.N.; Ekosse, G.-I.E.; Odiyo, J.O.; Ogola, J.S. Mineralogical Characteristics of Cretaceous-Tertiary Kaolins of the Douala Sub-Basin, Cameroon. J. Afr. Earth Sci. 2018, 141, 130-147. [CrossRef]

33. Bukalo, N.; Ekosse, G.-I.; Odiyo, J.; Ogola, J. U/Pb LA-SF-ICP-MS Dating of Detrital Zircons in Cretaceous-Tertiary Kaolins in the Douala Sub-Basin, Cameroon: A Neoproterozoic Provenance. J. Afr. Earth Sci. 2018, 147, 554-568. [CrossRef]

34. De Araújo Santos Júnior, A.E.; Rossetti, D.F. Depositional Model of the Ipixuna Formation (Late Cretaceous-? Early Tertiary), Rio Capim Area, Northern Brazil. Lat. Am. J. Sedimentol. Basin Anal. 2006, 13, 101-117.

35. Sousa, D.J.L.; Varajão, A.; Yvon, J.; Da Costa, G.M. Mineralogical, Micromorphological and Geochemical Evolution of the Kaolin Facies Deposit from the Capim Region (Northern Brazil). Clay Miner. 2007, 42, 69-87. [CrossRef]

36. Domínguez, E.; Iglesias, C.; Dondi, M. The Geology and Mineralogy of a Range of Kaolins from the Santa Cruz and Chubut Provinces, Patagonia (Argentina). Appl. Clay Sci. 2008, 40, 124-142. [CrossRef]

37. Domínguez, E.; Dondi, M.; Etcheverry, R.; Recio, C.; Iglesias, C. Genesis and Mining Potential of Kaolin Deposits in Patagonia (Argentina). Appl. Clay Sci. 2016, 131, 44-47. [CrossRef]

38. Dondi, M.; Iglesias, C.; Dominguez, E.; Guarini, G.; Raimondo, M. The Effect of Kaolin Properties on Their Behaviour in Ceramic Processing as Illustrated by a Range of Kaolins from the Santa Cruz and Chubut Provinces, Patagonia (Argentina). Appl. Clay Sci. 2008, 40, 143-158. [CrossRef]

39. Olabode, S.O.; Mohammed, M.Z. Depositional Facies and Sequence Stratigraphic Study in Parts of Benin (Dahomey) Basin SW Nigeria: Implications on the Re-Interpretation of Tertiary Sedimentary Successions. Int. J. Geosci. 2016, 7, 210-228. [CrossRef]

40. Anoh, N.O.; Petters, S.W. Preliminary Investigation of Late Turonian-Early Campanian Shallow Marine Foraminifera of the Mungo River/Logbadjeck Formation, NW Douala Basin, Cameroon. J. Afr. Earth Sci. 2014, 99, 442-451. [CrossRef]

41. Paredes, J.M.; Aguiar, M.; Ansa, A.; Giordano, S.; Ledesma, M.; Tejada, S. Inherited Discontinuities and Fault Kinematics of a Multiphase, Non-Colinear Extensional Setting: Subsurface Observations from the South Flank of the Golfo San Jorge Basin, Patagonia. J. S. Am. Earth Sci. 2018, 81, 87-107. [CrossRef]

42. Oyebanjo, O.M. Paleo-Environmental Conditions and Tectonic Settings of Cretaceous-Tertiary Kaolins in the Eastern Dahomey and Niger Delta Basins in Nigeria. Ph.D. Thesis, University of Venda, Thohoyandou, South Africa, 2018, unpublished.

43. Oyebanjo, O.; Ekosse, G.-I.; Odiyo, J. Hydrogen and Oxygen Isotope Composition of Selected Cretaceous and Paleogene/Neogene Kaolins from Nigeria: Paleoclimatic Inferences. Appl. Clay Sci. 2018, 162, 375-381. [CrossRef]

44. Oyebanjo, O.; Ekosse, G.-I.; Odiyo, J. Physico-Chemical, Mineralogical, and Chemical Characterisation of CretaceousPaleogene/Neogene Kaolins within Eastern Dahomey and Niger Delta Basins from Nigeria: Possible Industrial Applications. Minerals 2020, 10, 670. [CrossRef]

45. Bukalo, N.N. Paleoenvironmental Reconstruction of Cretaceous-Tertiary Kaolin Deposits in the Douala Sub-Basin in Cameroon. Ph.D. Thesis, University of Venda, Thohoyandou, South Africa, 2017, unpublished.

46. Bukalo, N.; Ekosse, G.-I.; Odiyo, J.; Ogola, J. Paleoclimatic Implications of Hydrogen and Oxygen Isotopic Compositions of Cretaceous-Tertiary Kaolins in the Douala Sub-Basin, Cameroon. Comptes Rendus Geosci. 2019, 351, 17-26. [CrossRef]

47. Bukalo, N.; Ekosse, G.-I.; Odiyo, J.; Ogola, J. Geochemistry and Possible Industrial Applications of Cretaceous-Tertiary Kaolins of the Douala Sub-Basin, Cameroon. Period. Mineral. 2020, 89. [CrossRef]

48. de Araújodos Santos, A.E., Jr.; de FátimaRossetti, D.; Murray, H.H. Origins of the Rio Capim Kaolinites (Northern Brazil) Revealed by $\Delta 18 \mathrm{O}$ and $\Delta \mathrm{D}$ Analyses. Appl. Clay Sci. 2007, 37, 281-294. [CrossRef]

49. Pruett, R.J. Kaolin Deposits and Their Uses: Northern Brazil and Georgia, USA. Appl. Clay Sci. 2016, 131, 3-13. [CrossRef]

50. dos Santos, E.; Scorzelli, R.B.; Bertolino, L.C.; Alves, O.C.; Munayco, P. Characterization of Kaolin from the Capim River Region-Brazil. Appl. Clay Sci. 2012, 55, 164-167. [CrossRef] 
51. Baioumy, H.M.; Gilg, H.A.; Taubald, H. Mineralogy and Geochemistry of the Sedimentary Kaolin Deposits from Sinai, Egypt: Implications for Control by the Source Rocks. Clays Clay Miner. 2012, 60, 633-654. [CrossRef]

52. Roser, B.P.; Korsch, R.J. Provenance Signatures of Sandstone-Mudstone Suites Determined Using Discriminant Function Analysis of Major-Element Data. Chem. Geol. 1988, 67, 119-139. [CrossRef]

53. Nesbitt, H.; Young, G. Prediction of Some Weathering Trends of Plutonic and Volcanic Rocks Based on Thermodynamic and Kinetic Considerations. Geochim. Cosmochim. Acta 1984, 48, 1523-1534. [CrossRef]

54. Hofer, G.; Wagreich, M.; Neuhuber, S. Geochemistry of Fine-Grained Sediments of the Upper Cretaceous to Paleogene Gosau Group (Austria, Slovakia): Implications for Paleoenvironmental and Provenance Studies. Geosci. Front. 2013, 4, 449-468. [CrossRef]

55. Jones, B.; Manning, D.A. Comparison of Geochemical Indices Used for the Interpretation of Palaeoredox Conditions in Ancient Mudstones. Chem. Geol. 1994, 111, 111-129. [CrossRef]

56. Gross, M.G. Heavy-Metal Concentrations of Diatomaceous Sediments in a Stagnant Fjord. In Abstracts for 1963: Abstracts of Papers Submitted for Six Meetings with Which the Society was Associated; Special GSA Papers Number 76; Geological Society of America: New York, NY, USA, 1964.

57. Landergreen, S.; Manhem, P. Geochemical Facies Analysis Methods in Geochemistry and Geophysics II; Elservier Publishing Company: Amsterdam, The Netherlands, 1963; Volume 101.

58. Whiteman, A.J. Nigeria: Its Petroleum Geology, Resources and Potential; Graham and Trotman: London, UK, 1982; Volume 1, ISBN 94-009-7361-6.

59. Ajayi, T.R.; Oyawale, A.A.; Islander, F.Y.; Asubiojo, O.I.; Klein, D.E.; Adediran, A.I. Trace and Rare Earth Elements Geochemistry of Oshosun Sediments of Dahomey Basin, Southwestern Nigeria. J. Appl. Sci. 2006, 6, 2067-2076. [CrossRef]

60. Ntamak-Nida, M.-J.; Baudin, F.; Schnyder, J.; Makong, J.-C.; Komguem, P.B.; Abolo, G.M. Depositional Environments and Characterisation of the Organic Matter of the Lower Mundeck Formation (Barremian ?-Aptian) of the Kribi-Campo Sub-Basin (South Cameroon): Implications for Petroleum Exploration. J. Afr. Earth Sci. 2008, 51, 207-219. [CrossRef]

61. Bhatia, M.R. Plate Tectonics and Geochemical Composition of Sandstones. J. Geol. 1983, 91, 611-627. [CrossRef]

62. Murray, H.; Janssen, J. Oxygen Isotopes-Indicators of Kaolin Genesis. In Proceedings of the 27th International Geological Congress, Moscow, Russia, 4-14 August 1984; VNU Science Press: Utrecht, The Netherlands, 1984; Volume 15, pp. $287-303$.

63. Mizota, C.; Longstaff, F.J. Origin of Cretaceous and Oligocene Kaolinites from the Iwaizumi Clay Deposit, Iwate, Northeastern Japan. Clays Clay Miner. 1996, 44, 408-416. [CrossRef]

64. Savin, S.M.; Epstein, S. The Oxygen and Hydrogen Isotope Geochemistry of Clay Minerals. Geochim. Cosmochim. Acta 1970, 34, 25-42. [CrossRef]

65. Sheppard, S.M.; Nielsen, R.L.; Taylor, H.P. Oxygen and Hydrogen Isotope Ratios of Clay Minerals from Porphyry Copper Deposits. Econ. Geol. 1969, 64, 755-777. [CrossRef]

66. Gilg, H.A. D-H Evidence for the Timing of Kaolinization in Northeast Bavaria, Germany. Chem. Geol. 2000, 170, 5-18. [CrossRef]

67. Baioumy, H. Hydrogen and Oxygen Isotopic Compositions of Sedimentary Kaolin Deposits, Egypt: Paleoclimatic Implications. Appl. Geochem. 2013, 29, 182-188. [CrossRef]

68. Dill, H.G.; Bosse, H.-R.; Henning, K.-H.; Fricke, A.; Ahrendt, H. Mineralogical and Chemical Variations in Hypogene and Supergene Kaolin Deposits in a Mobile Fold Belt the Central Andes of Northwestern Peru. Miner. Depos. 1997, 32, 149-163. [CrossRef]

69. Clauer, N.; Fallick, A.E.; Galán, E.; Aparicio, P.; Miras, A.; Fernández-Caliani, J.C.; Aubert, A. Stable Isotope Constraints on the Origin of Kaolin Deposits from Variscan Granitoids of Galicia (NW Spain). Chem. Geol. 2015, 417, 90-101. [CrossRef]

70. Galán, E.; Aparicio, P.; Fernández-Caliani, J.C.; Miras, A.; Márquez, M.G.; Fallick, A.E.; Clauer, N. New Insights on Mineralogy and Genesis of Kaolin Deposits: The Burela Kaolin Deposit (Northwestern Spain). Appl. Clay Sci. 2016, 131, 14-26. [CrossRef]

71. Scotese, C.R. Atlas of Earth History; Paleogeography; PALEOMAP Project: Arlington, TX, USA, 2001; Volume 1, p. 52. 